\title{
Wuraola Esan as Educationist
}

\author{
Ezekiel Oladele Adeoti \\ Lagos State University, Ojo, Nigeria.
}

\begin{abstract}
This paper is a biographical study of a Nigerian woman educationist, Wuraola Esan with special focus on her contribution to the promotion of female education. It locates the neglect of female education on socio-religious and cultural beliefs, and therefore conceives in general terms the activities of Mrs. Wuraola Esan (centred in Ibadan), and in particular, her efforts towards the social emancipation of the female gender. Based on original and primary sources, the paper highlights the role of private endeavour/initiatives, as exemplified by the subject of study, in Nigeria's educational development.

Keywords:Wuraola Esan, Nigerian Education, Female Education, Female Gender, Educational Development.
\end{abstract}

\section{Introduction}

No doubt, the gender question that perceives women as integral in contemporary discourse on development and democratization world-wide is now an established fact. For too long women have been perceived in various societies, particularly in the developing world, as secondary citizens and objects of developmental and governance processes. Women are also often credited for producing up to 70 percent of the food requirements in the developing countries of Africa, and are responsible for looking after the home and society; yet, they are not fully recognized as partners in the development processes in their various communities. Societal stereotypes about women in the developing nations have not helped matters. Even governments that are supposed to protect the interest of women have consistently tried to and even succeeded in marginalizing women who constitute more than half of the entire humanity.

For along time, African women were not encouraged to play any meaningful and effective role in societal affairs like political, religion and governance: Women were made to believe that their rightful place was in the homefront as housewives, producers and minders of children. They were expected to stay at home and inculcate in their children the virtues of life while their husband's carried on with important societal tasks such as politics and governance.

However, there have been changes overtime. These started with women themselves who stoutly challenged their subordinate status in society. A major breakthrough came in the 1970's with the declaration of 1975 - 1986 as the Decade of women by the United Nations. Since then, many important conferences have been held in different parts of the world to advance the cause of women socio-economic and political empowerment. The most important of these being the Beijing Conference of 1995 whose platform of action has provided the basis for national action in many countries of the world. With that the woman question has been put on the sharp edge of global developmental politics. Prior to this development, Nigeria had produced a number of women under various guises who had succeeded in championing the interest of women in politics, and education. Wuraola Esan was one of such women. Here was a personage who championed the empowerment of women as far back as the colonial period in Nigeria with its inherited patriarchal institutions. This study is an assessment of the contribution of Mrs. Wuraola Esan, one of Nigeria's foremost female nationalists and educationists, to the development of education of the girl-child in Ibadan, Africa" largest indigenous city, south of the Sahara.

\section{Family Background and Early Education}

Wuraola Adepeju was born sometime in March, 1909 to the famous Christian Ojo-badan family of Ibadan. Her father, Thomas Ojo-Ade, was a veteran soldier of the First World War and the Ekarun (Fifth in line of succession to the (Olubadan) of Ibadan. Even though, Thomas Ade-Ojo professed to the religion of Christianity, he was an unrepentant polygamist with eight wives. Wuraola's father was a farmer until he enlisted as a soldier in the colonial army, the Royal West African Frontier Force (WAFF). He participated in the Asante Campaign and during the First World War, fought in the Cameroons. For over twenty five years, Chief Ade-Ojo served in the WAFF attaining the rank of Regimental Sergeant. He got several military awards for his gallantry and service in the British colonial army.

After his retirement from the Army, Chief Ade-Ojo was appointed Chief Manager of the Ibadan Forest Reserve in 1930. He was a staunch member of the Baptist Church at Idikan, Ibadan for most of his adult life. He was also among those who founded the Salem Baptist Church now based at Yemetu Alaadorin, Ibadan in 1953. Chief Ade-Ojo played an active role in Ibadan politics. And in recognition of his patriotism, he was 
conferred with a chieftaincy title of Gbonka-Balogun (Lord of War) of Ibadan. Before he passed on in 1954, Chief Ade-Ojo had become the Ekarun Balogun, fifth in rank to the Olubadan of Ibadan.

Wuraola's Mother, Madam Ajike Ojo Aina popular called. Iya Gbogbo (mother of all) was a self-made business woman. She occupied the second position in her husband's harem. She too, like her husband, did not have the benefit of going to school but she was widely traveled. In the course of doing business, she traveled to far-flung places like Onitsha in Igboland and Calabar in the South-Eastern part of Nigeria. Her exposure and interaction as a long distance trader afforded her the rare opportunity to learn how to count in hundreds and communicate in passable English. She was a successful trader dealing in kolanut and alligator pepper. She made much money and was able to assist her husband in taking care of the family whenever her husband was on his military assignment. Chief Ade-Ojo had twelve children. ${ }^{1}$ Thus, it could be seen that Wuraola came from an enlightened and influential family in Ibadan. ${ }^{2}$

As at the beginning of the twentieth century, the British colonial administration did not encourage the education of girls in Nigeria. The conservative Victorian values of the colonial administrators considered it natural for men to carry forth the economic role. ${ }^{3}$ It therefore gave little recognition to the traditional, economic and socio-political status of women. This also tallied with the patriarchal Yoruba attitude to the education of the girl-child that viewed women as appendages to be seen and not heard. This patriarchal perception informed society's orientation towards education of girls for a long time. For example, the ideal woman was one who was totally submissive to her husband and who remained faithful to her responsibilities as a good wife and mother. She was also expected to remain as a full housewife. Hence, Wuraola's mother's choice as a long distance trader was something out of the ordinary in those days. Apparently, she had reached an agreement with her husband that she would forfeit a substantial portion of her business earnings to him upon each return from her business trips. There is no evidence that she reneged on this informal agreement. ${ }^{4}$

Among the Yoruba, women dependency on their husbands was strengthened by patriarchal structures which contributed to limiting access of the girl-child to incipient Western education. In the heydays of colonial rule when Wuraola was growing up, the only schools available for girls were mostly missionary schools. These Christian missionaries emphasized only those skills and learning that would make the girl-child a good housewife and of course the scriptures were important components of the school curriculum.

The parents of Wuraola must have recognized the importance of the acquisition of Western education for both boys and girls through their experiences. The father had served in the colonial army and, the mother, as an itinerant trader, must have come across many educated people and would therefore wish their children to be educated. Thus, the acquisition of Western education by their child was a primary concern. It was not surprising that Wuraola attended many schools in the South-Western and Eastern regions of Nigeria. She attended the Sacred Heart Covenant, Ibadan, for her primary education between1921and 1923. She later went to Sacred Heart Covenant School in Calabar between 1923 and 1925. She also attended Idi-Aba Baptist Girls School, Abeokuta, between1926 and 1927. Later, she went to pursue her teacher training education at the United Missionary College (UMC), Molete, Ibadan between 1927 and 1929. Wuraola took to teaching thereafter. For educated women in Western Nigeria society during the colonial rule, teaching was the most common profession. Several reasons can explain this phenomenon. Firstly, it afforded nursing mothers the opportunity to have quality time to cater for their babies after school hours. Secondly, unlike their civil servants counterparts, teachers enjoy longer holidays. Thirdly, women teachers enjoy the benefit of three months maternity leave and this enables them to take care of their children. Fourthly, teaching was considered less strenuous and easier to get. Besides, Wuraola had a passion for teaching. Perhaps, the most crucial influence on Wuraola regarding her love for the "chalk and board" profession was her elder brother, Joseph Adeyemi Ade-Ojo, who incidentally was a teacher at the Prestigious King's College, Lagos. ${ }^{5}$

During her school days, Wurola was exposed to a variety of subjects where she excelled as a very brilliant and hardworking student. At the Teachers College, she studied Arithmetic, English, Elementary Science and Domestic Science. Her classmates at the U.M.C included Miss Alalade, who later became Mrs. E.O. Aboderin, Miss Fajembola, later Madam Mosebolatan, Miss Akinyemi later Madam Adewusi, Miss Abigail Ajayi, later Mrs. Ogunde, Miss Comfort Folase who later became Mrs. Fasuyi, among others.

As a student, Wuraola took active interest in extra-curricular activities. She was a leading member of the Literary and Debating Society where she excelled as a debater.

\section{Teaching Career}

On completion of her studies at the U.M.C. in 1929, Wuraola was employed as a teacher at the Akure Women's Center, where she taught the wives of Christian missionaries. The Akure Women's Training Institution was not a regular school but just a centre set up for training girls for marriage and for those who had already become wives of Anglican priests to be good mothers. ${ }^{6}$ 
The curriculum of the Centre included both practicals and literary studies. Under the practical section, the emphasis was on sewing and dress-making. The syllabus included subjects like Arithmetic, Reading and Writing (popularly called the 3Rs), Mother-craft, English, Singing, Hygiene and Physical training (PT). On the practical side, were courses like laundering, mending, Yoruba, cookery, dress-making, English-cooking and gardening. The idea behind this was to instill in them European rather than African values. Wuraola's annual salary while at the Centre was a paltry thirty two pounds, sixty five shillings and nine pence $(£ 32: 65: 9 \mathrm{~d} \text {. })^{7}$ Yet, she distinguished herself as a teacher.

Wuraola personified all the facets of a model teacher in a Christian institution. Unlike modern teachers whose attitude to teaching is "teach and go", the typical mission teacher of old was a man or woman of many parts who worked literally twenty four hours a day. He or she was expected to be not only the master of his or her subjects, but in addition, he/she was to function as counselor, guide, leader, an engineer of relevant activities in the personality-building process, and moral reformer of his/her erring students. ${ }^{8}$ Looking at Mrs. Esan from these perspectives, one readily comes to the conclusion that she was an ideal teacher and a role-model. A relevant testimony at this juncture was the commendation of Miss Gertrude Plummer, the famous Superintendent of Education, Western Provinces. In her report on the Akure Training Institution, Miss Plummer commented that Mrs. Wuraola Esan was excellent. She went further to say that her solid and sound methods were no doubt a reflection of her solid and sound character which had been an asset of great value to the centre. In all her assignment at the College,Wuraola laboured to transmit to her students that sense of order, discipline and control, instilling in them a powerful stimulus, which urged them to take their destinies in their hands. ${ }^{9}$ Her stint at the Centre lasted till 1935, when she left Akure for Methodist Girls School, Yaba, Lagos.

This school was founded in 1879 and was then known as the Methods Girls High School (MGHS). ${ }^{10}$ The school has played a significant role in the secondary education of the girl-child not only in the SouthWestern part of Nigeria in particular but also in Nigeria in general. During her brief stay in the school, Wuraola left behind her a good legacy of service. As a House mistress, Wuraola was feared for her discipline. She had no room for indolent and lawless students. She was not known for any double-standard. She handed down punishment to erring senior students just as she did to the juniors. There were no special laws for the seniors as she always believed in equity and justice. And as a classroom teacher, Wuraola was an enthusiastic tutor who infected her students with her own zeal. She encouraged bright students by giving them occasional gifts and helped the diffident to gain greater confidence. ${ }^{11}$

\section{Matrimony}

Before her departure from Akure Women Training Centre, Wuraola got married. Well before her engagement, Wuraola had displayed a rare gift of clairvoyance. She claimed to have seen 'Victor', the name of her future husband, written on a piece of paper placed before her in one of her dreams. As at the time of this dream, she had not met in person anybody called Victor. As it turned out providentially, she later met Victor at her cousin's house. That cousin was the late Mr. Adesina Falola popularly called "master Tailor". Wuraola often spent her holiday period with her popular cousin. It was on one of these periodic visits that she eventually met victor, her future husband.

Victor Owolabi Esan was a civil servant at the Ibadan City Council. Like Wuraola, Victor also came from an influential Christian family in Ibadan. Both of them got wedded on 27 April 1938.The marriage was blessed with four children, two sons and two daughters, namely, Olabamiji, Oluwatoyin (sons), Yetunde later Chief (Mrs.) Y.O. Omisade and Jadesola who later became Professor (Mrs.) Jadesola Akande (daughters). In 1944, Victor Esan travelled to England to pursue a course in Law.

Wuraola later resigned her teaching appointment at MGHS and returned to Ibadan to start a new life independent of her husband. In those days, the Nigerian Youth Movement (NYM) and, the National Council of Nigeria and Cameroons (NCNC) were very active in the politics of Lagos. Women played active role in both movements. There was also the Lagos Women's League, headed by the indomitable Mrs. C.O. Obasa, which gave active support for education of girls and even visibly put pressure on the colonial authority to provide more opportunities for girls. These movements largely inspired Wuraola to develop interest in education of girls and political activism. ${ }^{12}$

\section{Wuraola as a Politician}

In 1954, she took a chieftaincy title and in 1958, she was elected to the Ibadan Urban District Council. It is well known that Wuraola was the first woman member of the Nigerian Senate in the first Republic. She was appointed in 1960 to represent the Western Region. Wuraola was also deeply involved in community political activities. In 1975, she was awarded the highest chieftaincy title open to women in Ibadan, the powerful and prestigious Iyalode of Ibadan. Occupiers of this office are traditionally selected on merit and are women who have made enormous contributions to Ibadan before being awarded the title. However, it was in the field of education that Mrs. Esan was known to have contributed largely to the development of Ibadan. 


\section{The State of Girl-Child Education in Ibadan}

Wuraola Esan wanted to ensure that illiteracy amongst the women folks became a thing of the past in Ibadan. She believed that one of the means by which ignorance could be totally wiped out in the society was acquisition of Western form of education. This remained her guiding philosophy in life. Even though, she later found herself in the murky waters of politics under Chief Obafemi Awolowo, she practically gave her life to the promotion and enhancement of girls education in Ibadan.

In 1945, Mrs. Wuraola Esan resigned her teaching appointment and returned to Ibadan to pursue her life ambition of becoming a promoter of female education, established schools for girls as she awaited the return of her husband from overseas.

Before we go into Wuraola Esan's educational ventures, it is germane at this point to pause and examine the state of colonial education particularly as it affected the girl-child in Ibadan in the 1940s with a view to understanding the contributions of Wuraola to the promotion of girl-child education in Ibadan and beyond.

By 1945, only about 20 percent of the pupils in the whole of Yorubaland were girls. Most of these girls had no access to western education because of a combination of factors, namely, lack of awareness on the part of parents on the need for girl-child education, inability to generate funds for the education of their children and the fact that schools were few not only in number but also in level. There were only 214 schools in the whole of Ibadan province and, of this number, only 36 were beyond the elementary level. Average attendance in all the schools in the province was 11,130 out of a population estimate of $1,342,259 .{ }^{13}$ In many parts of Yorubaland, efforts were being made to encourage and promote the education of girls. Among the Ijebus and Ekitis, in particular, there was much enthusiasm. But in Ibadan, there was a total lack of interest. ${ }^{14}$

The Native Authority (N.A.) showed an interest in education including the Elementary Training College which provided the teachers for their schools. So, too, were the Muslims who established two small Islamic Primary Schools at Ibuko and Odo-Oye so that their children could escape the proselytizing influence of Christian Mission Schools. Even though the Missions showed interest, their proprietors had more zeal for church activities than for education. They justified their lukewarm attitude on the pretext that Christianity and Western education were yet to gain much acceptance in Ibadan. ${ }^{15}$ Female education in particular was very backward. The Ibadan, like other Yoruba people, had not yet seen much benefits in it. There were of course girls in the few existing schools, but they were very few in number. One Miss Plummer, an European educationist, founded a Domestic Science Centre. However, the initial jubilation that heralded this laudable initiative did not last long as the graduates were unable to secure decent jobs in most government establishments. There was a preference for the CMS Boarding school at Yejide where the training in cookery was merely to complement the normal curriculum. On the whole, female education trailed behind that of boys. ${ }^{16}$ Of the total number of 3440 students in Ibadan in 1940, only 670 representing 22.1 percent were girls. ${ }^{17}$ This shows that the ratio of girls to boys stood at 1 to 5 . This may be taken as a fair indication of popular feelings towards female education. Most of the schools in Ibadan were for boys. It was only in 1941 that admission of girls into the Native Authority Schools started receiving some kind of encouragement. ${ }^{18}$ The expected expansion was constrained by the increase in school fees by the N.A. Schools to bring them at par with the Christian mission schools. ${ }^{19}$ It took a long time before most parents realized the value of girl-child education and the need to send their daughters to school.

From the economic point of view, many parents considered education of girls as a waste of money. Such parents believed that money spent on girls education was a waste since they would soon marry into their husband's family. They did not appreciate the fact that girls could be as helpful as boys to their parents, more so when it comes to taking care of their parents at their old age. Many parents also believed that they would not only lose the labour of their daughters who attended school, but that such daughters would in addition, be rendered illprepared for the responsibility of married life in the traditional setting. There was the belief that an educated girl would have a narrow circle of suitors since no man would want to undermine his own status by marrying a girl whose educational accomplishment was demonstrably higher than his. ${ }^{20}$

There were also religious constraints. Ibadan was, and still is, a multi-religious society where many people profess Islam, Christianity and African traditional religion. Islam, like Christianity holds that man should be the head of the family. In traditional religion, women must always stay in the background. ${ }^{21}$ That perhaps explains why women are often kept out of shrines and the cults of most traditional religions. ${ }^{22}$ The Ibadan of the 1940s was largely rural and less sophisticated. The fact is that, ignorance was for a long time the bane of girl education in Ibadan, as in many parts of Nigeria. This was the position when Mrs. Wuraola Esan came back from Lagos in 1945. It was left to her to take a decision on her next move. 
For Ibadan to move forward and progress, all forms of discrimination and constraints against girls' education must be removed. Equal educational opportunities must be created. On that basis, Wuraola Esan made it a point of duty to establish her own girl schools as part of the strategies for eliminating discrimination and breaking the barriers against girls' education and promoting same.

Wuraola was not alone in the quest to promote the education of girls in the country. She was perhaps, influenced by leading advocates of girls' education whose opinions and pronouncements were being made public in the popular print media of the time. For example, one Mr. J.E. Kpoko, an Urhobo advocate of girls' education wrote an article in the Southern Nigeria Defender of 8 January, 1945 where he canvassed the need for education of girls as the only antidote to ignorance and the only means of attaining desired progress in our society. According to him,

\section{Women should not be denied opportunity of drinking deep from the fountain of knowledge which will remove the scales of intellectual darkness from peoples eyes to enable them to see the light. ${ }^{23}$}

Mr. Okpoko also noted that a woman with minimal level of western education would know best how to balance the household budget and influence the mind of her little children and that education enables women to discharge their responsibilities more effectively and efficiently.

Undoubtedly, education of women is crucial to development as it has multiplier effects. This is because, as mothers, their training influences their children with respect to intellectual, socio-cultural and spiritual or moral development. Similarly, education has the capacity and potential of assisting women to become enlightened, acquire useful and relevant skills and imbibe functional literacy. This in turn will help to liberate their minds from superstitions, ignorance and disease. Thus, through education, women understand the nutritional needs of their children whose health constitutes vital asset to national development. ${ }^{24}$

Education of illiterate women can help them to acquire basic functional literacy and numeracy which consequently could improve their occupation or trade as market women, farmers, entrepreneurs and so on. In fact, women need education more than men as exemplified by this notable quotation: "Educate a man and you educate an individual, but educate a woman and your educate a nation". ${ }^{25}$

Ideas like the above were often canvassed on the pages of many newspapers at that time. For instance, Lady Oyinkansola Abayomi and Mrs. C.O. Obasa, two pioneer advocates of women education once said that an educated housewife had better knowledge to keep and nurture her children properly and efficiently than the one who did not have it. Such woman also offered truly intelligent love and companionship to her husband. This is not to say that illiterate women are incapable of doing so. However, education helps to perform these responsibilities much more effectively and efficiently. Thus, they argued that it is important that the girl-child must be encouraged like their male counterparts to go to school. ${ }^{26}$ The pioneering role of lady Oyinkansola Abayomi and Mrs. C.O. Obasa was, perhaps, not lost on Mrs. Wuraola Esan. This probably explains why Wuraola decided to be an active promoter of girls' education in Ibadan as the duo of Abayomi and Obasa were doing in Lagos.

Another notable development which worked in favour of Mrs. Esan was the existing government educational policy. The first was the 1925 Memorandum on Education Policy in British Tropical Africa which formulated broad principles that should form the basis of a sound educational policy in Nigeria and which unequivocally supported education of girls and women. ${ }^{27}$ The second had to do with regulation and control of new schools that were being established by individuals and missionary agencies in Ibadan province in the 1930s and 1940s. The policy was aimed at controlling the expansion of schools within financial limits. In the 1940s, the policy would appear to be ineffective as the demand for more schools was such that, despite all the powers conferred on the Education Department by the 1926 Education Ordinance, government could still no longer prevent the missions, local authorities, and individuals from indiscriminate establishment of the so called hedge schools. ${ }^{28}$ As from the 1930s, applications were pouring into the office of the Senior Education Officer (SEO), Oyo Province, Ibadan requesting that permission be granted to open new schools. After the D.O. had properly scrutinized the application, he would then send replies on whether or not there was political objection. There were also considerations as whether or not the individual or the mission applicants had the right calibre of teaching facilities and personnel. ${ }^{29}$ Low qualifications were allowed in respect of elementary vernacular schools and, by taking off with them, the proprietor hoped the schools would gradually be upgraded under favourable circumstances in the future. ${ }^{30}$ This process would appear to have paid off with the rising demand for more 
schools and increasing realization of their benefits. In the 1930s and 1940s, many elementary vernacular schools were licensed by government to open. ${ }^{31}$

\section{Wuraola: The School Proprietor}

Mrs. Wuraola Esan was among the lucky applicants that met the stringent requirements and granted approval to open new schools. She established two elementary schools at the same time namely, Ibadan Peoples Girls School and Dorcas Memorial Nursery Schools (named after her mother). ${ }^{32}$ The two schools started as elementary vernacular schools hoping to be upgraded under more favourable conditions in the future. The two schools were approved by the District Officer (D.O.) on the 8 August, 1944. One Miss Gertrude Plummer, the then Superintendent of Education, (S.E.) in Oyo provinces recommended the school for approval.

Miss Gertrude Plummer had been associated with girls education in the Western provinces since the 1930s. ${ }^{33}$ She was known to have always been mounting pressure on the various missionary bodies as well as the colonial authority to pay more attention to education of girls by giving grants and aids for the establishment of girls schools. Two factors may have favourably disposed Mrs. Plummer to grant approval to Mrs. Esan's application. In the first place, both of them shared the same view on the necessity of promoting girls education. Secondly, Miss Plummer was an admirer of Mrs. Esan. Plummer had earlier met Mrs. Esan as a teacher in Akure Women Training Institution and had in her assessment commended her for her high level of professionalism and efficiency as a teacher. ${ }^{34}$ This is not to suggest that Mrs. Esan did not meet the minimum requirements set by the Colonial Education Authority. Hence, Mrs. Wuraola Esan joined the league of Private School Proprietors which included the like of Chief T.L. Oyesina, founder of the famous Ibadan Boys High School, Oke-Ado, Ibadan. ${ }^{35}$ This marked the beginning of her eventful career as a school proprietor.

Ibadan Peoples Girls School initially started as a co-educational school, admitting both boys and girls because there were not enough girls registering to make the venture viable. Enrolment had to be beefed up with admission of boys into the school. Later, the boys were transferred to other schools after elementary two.

\section{Her Admission Policy}

Her school admission policy was all inclusive. It was neither restricted to, nor discriminated against practitioners of a particular religion. Although, Wuraola was raised as a Christian, her admission policy was not biased towards girls from non-Christian homes. She gave equal opportunities to all girls who desired placement in her school irrespective of their families religious affiliations. She took the interest of non-Christians, particularly Muslim girls, into consideration. Perhaps, she was worried that the Muslims who formed a large section of Ibadan were not sending their children especially girls in corresponding numbers to Christian-run schools. Many of such schools were seen as avenues of converting non-Christians, particularly Muslims, to Christianity. Because of this, many parents refused to send their children to Christian-managed schools for fear of proselytizing. The result was that the education of Muslim girls and boys lagged behind. Wuraola Esan's desire was to put an end to this and ensure that equal opportunity was given to every girl-child who wanted to go to school. She often went round from house to house appealing to Muslim parents to enroll their female children in her school. Many Muslim girls were admitted into the school without any pre-condition. ${ }^{36}$ Mrs. Esan did not deliberately go out of her way to convert any of them to Christianity, though there is no doubt that the religious atmosphere of the school left a permanent stamp on those who attended it. There was that pervasive influence of Christianity because it was still compulsory for all the children to attend morning devotional services where they listened to Bible exhortations. Quite a number of these girls may have been converted in the process.

The school suffered a paucity of teaching personnel at its inception. When it took off in January 1945 with 18 students, Wuraola Esan and another female assistant were the only teachers. The first site of the school was the "Amen House". The House belonged to the family of one Mrs. Williams at Agbokojo area of Ibadan. Wuraola and Mrs. Williams had been friends since their Teacher Training College days at U.M.C., Ibadan. The 'Amen House' served dual purposes: One, as the school premises, and two, as the official residence of the Esan family. Most of the pupils also lived with Mrs. Esan.

When Victor Esan, Wuraola's husband, came back from England on completion of his law programme in 1948, he met his wife and children almost living in penury as Wuraola tried to sustain her school by all means, Wuraola was in dire financial stray. Barrister Victor Esan would not allow this to continue. His proffered solution to his wife's financial challenge was to advise Wuraola to close down the school while he struggled to make money to off-set her outstanding debts. ${ }^{37} \mathrm{He}$ even suggested to the chagrin of Wuraola that he would prefer her becoming a full time house-wife so that she would have more time to take care of their young children. However, Wuraola had a contrary opinion. She announced to her bewildered husband that she was ready to sacrifice her marriage for her chosen career as a school proprietress. 
This misunderstanding led to frequent frictions and quarrels between Victor and Wuraola. Even the intervention of Wuraola's brother, Mr. S. Ade-Ojo, could not resolve the matter amicably. The impression should not be formed that the husband was jealous and did not want progress for his wife. Rather, what he wanted for his wife was a peace of mind and that he was ready to satisfy his wife's financial needs as a husband now that he had become a successful lawyer. The desire to relieve his wife of a serious financial burden was rather borne out of love and sympathy. When Victor realized that his wife was not ready to accede to his advice, he went ahead to give her all the assistance he could muster. He secured a piece of land for her at Laba-Owo in the Ogunpa area of Ibadan. The People's Girls School relocated to the new site in 1948.

It would appear Wuraola paid more attention to her school business and party politics than her husband. The irreconciliable differences between her and Victor, perhaps made Victor to relocate to Lagos to pursue his legal practice. The business prospects of Lagos as a thriving commercial centre may also have lured Victor to shift base to the city. Wuraola herself was now enmeshed in politics, coupled with her school activities led to her having little or no quality time for her equally busy husband. The couple arrived at a mutual agreement to separate as husband and wife. However, the care of the children was their joint responsibility as the children were always in Lagos to spend the holidays with their father.

Wuraola Esan soon realized that for her to be able to accommodate more students in her school, she needed to build a bigger school. In 1950, a more spacious site was acquired to provide adequate space for future expansion, Mrs. Esan had to personally scout for the new site for her school to relocate from Laba-Owo area of Ogunpa. To acquire a new site was a difficult task. Whatever property acquired, government approval was needed. Approval was not easy to obtain in those days because of the conditions laid down by the colonial government for school proprietors to satisfy before getting the required approval. Most times, she rode on her bicycle from Laba-Owo to the City hall at Mapo Hill, a distance of about thirty kilometers just to lobby government officials to either allocate her a piece of land or approve the one she had proposed to acquire for her school. A piece of land was eventually allocated to her in 1950 along Molete, an area that could be best described as a suburb of Ibadan township. Molete in those days was regarded as a place out of town on the Ijebu-Ode Road. It was popularly called Ijebu Bye-pass. As Wuraola did not have a better option, she accepted the offer. But getting needed funds to develop the new property was another big challenge she had to contend with as would be shown later.

On the attainment of new status, the school changed its name from the Ibadan Peoples Girls School to Peoples Girls School. It operated the Nursery/Primary, and Junior Secondary School system. Students were expected to spend a maximum of three years of comprehensive learning in line with the educational policy of the Western Regional Government. This policy, it must be emphasized was meant to cater for a middle level secondary education, so that children would not terminate formal learning before attaining the age of 15 . According to the policy, all secondary - modern schools should be transformed into junior secondary schools and opened on a fee-paying basis, while grammar schools were to be renamed senior secondary schools. The system was, however, phased out in 1961 because it was not having the desired effect. ${ }^{38}$ The phasing out of the policy gave Mrs. Wuraola Esan, the opportunity to convert her school to a full fledged secondary school. At the same time, she continued with Nursery/Primary school within the same compound. Thus, Wuraola became an all-round provider of comprehensive education for girls, a feat unequalled by any woman in Ibadan at that time.

\section{Welfare of Indigent Students}

It is important to emphasize that the attention that Wuraola Esan paid to education was largely to improve the lot of the less privileged in the society. While she sank her financial and other resources to her education project, pecuniary gains appeared not to be her desire. This is because she encouraged the education of the less privileged female students. At this point in time, many indigenous Ibadan families fell into this category and Mrs. Esan went out of her way to recruit children from such deprived and ignorant families. It is reported that Mrs. Wuraola Esan gave free uniforms where and when it was apparent that non-possession of them was affecting the integration of the girl-child into the school system. The most important thing for her was to help wipe out illiteracy and ignorance in all their ramifications amongst the women folks in her domain. It is relevant to note that Mrs. Esan insisted that no child should be sent out of school for non-payment of school fees or for not wearing the approved school uniform.

Initially, Dorcas Memorial School was moved out of proximity of the main Ibadan Peoples Girls School to the premises of the Young Women Christian Association (YWCA) at Oke-Bola from where it was later moved to another building in the same vicinity, which is now the present site of the famous Odusote Bookshop, Oke-Ado 
area of Ibadan Metropolis. In 1963, it was relocated to a new piece of land acquired by Mrs. Esan along the New Ade-Oyo Hospital Road off the Ring Road in Ibadan. With this development, the Nursery section was totally severed from the primary section. The primary school section later reverted to the old name, Peoples Primary School, because it had started admitting boys as well. ${ }^{39}$ The Dorcas Memorial/Primary School was expected to be the feeder for the secondary modern school. Both levels of schools were meant to cater primarily for indigent students in particular; girls from homes which were not yet convinced of the need for and importance of girls education.

Just as Mrs. Esan demonstrated her confidence in the quality of instruction being dished out by her school to the public by sending her own children to the school, many prominent families in Ibadan who believed in her mission shared her confidence and optimism by also sending their children and wards to her school. Most of the children of the popular Adebisi and Ojo-badan families as well as three of Wuraola's children attended the Peoples Primary School. These included Dr. Adebisi (later Professor) of the Political Science Department at the University of Ibadan, Ibadan; Harry Akande (later Chief) the politician, businessman and billionaire; Dr. Toyin Falola hitherto of the History Department, Obafemi Awolowo University, now the Higgenbotten Professor of History, University of Texas at Austin, United States of America; Chief Mrs. Yetunde Omisade who became the first principal of the Peoples Girls Grammar School, Molete, Ibadan; Professor (Mrs.) Jadesola Akande, eminent law scholar and former Vice-Chancellor, Lagos State University, Ojo, Lagos and Mr. Olutoyin Esan, an Ibadan based business tycoon. The last three names were children of Mrs. Wuraola Esan.

\section{Initial Developmental Challenges}

\section{Lack of Fund}

As the years wore on, Mrs. Esan, had serious challenges to contend with at the teething stage of development of the school. This had to do with lack of government recognition and paucity of funds to keep the school running. Wuraola was by no means wealthy and, therefore, one of the major challenges she encountered had to do with the continued financial sustainability of the school. In 1945, when she established the first school, she had been promised a grant from the Colonial Education Welfare Development Fund. But this did not materialize. After the school was given official recognition, it was not classified as one of those to be grantaided because it was not a mission school and was regarded as a private commercial enterprise. Most of the schools in Ibadan, as in other parts of Nigeria, were owned and managed by the Christian missions or Muslim missionary societies.

To compound the financial problem, many of the students admitted were either lured or 'conscripted' against their parents wishes to come to the school by Mrs. Esan. It was not surprising that the meager fees of five shillings charged per student per year was not even paid by many students. To keep on sustaining the school, Mrs. Esan had to source for money. However, it was difficult for her to get the kind of money she needed. There were few banking facilities in Ibadan. Mrs. Esan had no houses, property or business to use as collateral. Yet, she decided to borrow money with all the attendant problems. She probably had heard about problems of professional money lenders from Ijesa and Ijebu. Wuraola was desperate to take a loan. She shunned the Ijesa Osomaalo and opted to borrow some money from an old Ijebu money-lender popularly called Pa Odunsi. This, she supplemented with the fortune she inherited from her late mother's estate and her own meager personal savings during her teaching days. With all these, she was able to keep the school afloat. ${ }^{40}$

\section{Lack of Quality Teaching Personnel}

For her lack of financial resources, Wuraola could only get the services of non-graduate teaching personnel to get the school going. But she got the best out of them. With limited financial backing, there was the attendant problem of securing the services of good quality teachers. So, the challenge of the school being regarded as sub-standard was always there starring her in the face as most teachers preferred to work with the government or public schools where the prospects of receiving better and regular salaries were guaranteed. In most private school establishments, salaries were poor and not regularly paid. The situation was even worse in a school like Peoples Girls School that refused to charge high tuition fees and equally reluctant to enforce payment of fees. The need to protect her dignity and credibility or her avowed commitment to keep on promoting and supporting, female education may have been responsible for her patriotic gesture.

Nevertheless, Wuraola attracted a good crop of young dedicated female teachers, who on many occasions did not receive their salaries for months. They even gave the girls extra lessons when deemed necessary and helped maintain a high level of discipline in the school. Such teachers included one Miss Olowu, Miss Sonaike and another, Mrs. Olaopa. These pioneering and highly committed staff were paid only fifteen shillings per month. These three women, no doubt, shared the vision of Mrs. Esan about the education of girls and they stayed with 
her for many years. Together, they helped in bringing hope and stability to the school teaching system. ${ }^{41}$ On the 21 March, 1965, the Peoples Girls School finally transformed into a full fledged secondary school. The name of the school was changed to Peoples Girls Grammar School to reflect the new status.

In order to upgrade the school and make it eligible to present its students for the West African School Certificate Examination, Mrs. Esan had to sacrifice the career of one of her daughters in the government employ to head the school. This was with a view to making sure that the school obtained approval for the conduct of the West African School Certificate examinations. For a school to obtain such an approval, the Principal or Headmistress must be a university graduate. Graduates were very few and much in demand in both the private and public sectors. Much money was needed to pay them. Mrs. Esan could not afford to hire graduate teachers. She had to withdraw her own daughter, Mrs. Yetunde Omisade, a graduate of English of the University College of Ibadan, from the Ministry of Information where she worked as a Senior Information Officer to be the Pioneer Principal of the new Grammar School. ${ }^{42}$ This was a great personal sacrifice the young woman had to make in appreciation of her mother's love and care, in her quest to uplift the status of womanhood in contemporary Nigerian society.

The Peoples Girls Grammar School recorded phenomenal achievements. Under the principalship of Mrs. Yetunde Omisade, the school which took off with two classes of sixty-eight (68) girls grew to twenty-nine (29) classes with a student population of one thousand and twenty six (1026) students. ${ }^{43}$ It was during her tenure as pioneer principal that the first set of students was presented for the West African School Certificate Examinations in 1969. Young as the school was, Mrs. Esan promoted the teaching and study of science subjects. One Mr. V.A. Ola Olusanya, pioneered the teaching of Chemistry in 1970 with only thirty students. He also introduced science club with a view to encouraging more girls to get interested in the study of the sciences.

\section{Curriculum Development: Vocational Education}

Mrs. Esan displayed a rare gift of foresight as an educationist. This was evident in the curriculum she designed for her school from its inception. The curriculum emphasized the incorporation of life skills reminiscent of the kind of practical education she received as a student in the Teacher Training College. ${ }^{44}$ Subjects like Domestic Science and Home Economics were taught alongside traditional school subjects like Arithmetic, English, Bible Knowledge, Geography, Yoruba among others. In her bid to encourage her students to take active interest in these vocational subjects Mrs. Esan always organised annual competitions and awarded cash prizes to those who excelled in these subjects. ${ }^{45}$ Her own educational orientation at the U.M.C. and the Akure Women's Centre where she had been involved in the teaching of life skills, may have influenced her decision to float these subjects.

\section{Government Take-Over}

When Mrs. Esan was supposed to sit back and enjoy the fruit of her life long labour, the government of the day came out with a new policy that frustrated her hope. In line with government policy to take-over control of all schools in the Western State of Nigeria and to prevent so-called exploitative tendencies of some private school proprietors, and maintain high standards, the Peoples Girls Grammar School, like many others, was compulsorily acquired in 1975 with a compensation of a paltry sum of Twenty Two Thousand Naira (N22000). This was the government's cost of all the assets and life time investment and selfless service of Mrs. Esan. She was devastated, traumatized and she never got over the humiliation. However, she felt fulfilled that provision was made for the continuation of her life's ambition to bring education to the forgotten and neglected, to train the girls of Ibadan. Her mission was accomplished as she declared: "I have realized my dream",46

\section{Post-Retirement Service/Recognition}

In spite of government forceful take-over of her property, she never stopped associating with the school till she breathed her last. She served as a member of the Board of Governors where she had the opportunity to continue to deliberate on the planning and administration of the school. She had lived on the premises of the Peoples Girls Grammar School all through its developmental stages and had had no time and money to build a personal and befitting house for herself elsewhere in Ibadan-metropolis. The forceful acquisition of the school necessitated the demarcation of a small portion of which her residence stood from the rest of the school buildings. Mrs. Wuraola Esan continued to live on the school premises until her last day. Her house was next to the school hall and she could peep into the school compound and watch its development. However, she was also there helplessly watching its deterioration when successive military governments denied the school, like others of its kind, the necessary infrastructural facilities and attention it deserved. ${ }^{47}$ 
Apart from the Peoples Girls Grammar School, Mrs. Wuraola Esan also associated with the development of education in Ibadan in general. Her love for education went beyond her ownership of Peoples Girls Grammar School. She continued to offer useful suggestions on the planning and management of other educational institutions in Ibadan such as Yejide Girls Grammar School, Molete, Ibadan; Ibadan Boys High School; Ibadan City Academy; the Local Authority Teachers' College and her alma-mater, the U.M.C. at Oke-Ado, Ibadan. She was, in 1977, officially recognized by the UMC and honoured as a distinguished alumna when one of the popular hostels in the school was re-named after her. This was a unique achievement as no other alumna of the school before and after her has been so honoured. ${ }^{48}$

The Peoples Girls Grammar School, despite all odds, has continued to make enviable progress. Presently, the school has grown bigger and it is now divided into two - Junior and Senior Secondary schools. Both share the same compound but have different set of teachers, principals and vice principals. For easy accessibility, there is little difference in their uniforms in order to identify the junior students from the senior students' when they meet outside their classrooms. The School Library which has been named after Mrs. Wuraola Esan is a living testimony to the legacy of the woman who lived and labored for others to be emancipated from crass ignorance and want.

\section{An Assessment of Wuraola Esan's Contribution to Education}

Wuraola's advocacy and encouragement of girls education gave fillip to the education of young girls in Ibadan who had traditionally been regarded as less suited for academic pursuits than boys. At all events over the years, the composition of primary school classes on the basis of sex has changed radically. In Ibadan today, there are possibly more girls than boys in virtually every school, at least in the municipal area and, in the rural parts, girls account for probably half of the school population ${ }^{49}$ The increase in female enrolment suggests a significant change in the attitude of Ibadan parents towards the education of their daughters. The sudden realization that an educated girl could command higher bride price than an illiterate one may have also influenced the decision of many parents to send their daughters to school. Also, the increasing vocal advocacy of women liberation in the recent past may as well be regarded as a fall-out of Mrs. Esan's advocacy of mass literacy for girls and young women in Ibadan.

If the contribution of a school proprietor is measured by the contribution of her products to the community, Mrs. Wuraola Esan achieved a large measure of success as an educationist. Prior to the 1960's, many Ibadan sons and daughters could hardly be found in the professions, executive or administrative positions, in the government ministries and parastatals. Ibadan was in this regard unable to compete with other parts of South-Western part of Nigeria. This changed with the intervention of Mrs. Esan and others of her mould. Many of her products are today in top posts in professional branches of the civil service. Since the 1960s, Peoples Girls institution graduates have blossomed and taken leading positions in the society. Reportedly, some of them have become High Court Judges and eminent advocates and solicitors. Many have gone into other forms of selfemployment in which they are giving leadership. The list is a long one but medicine, nursing, teaching, school administration, accountancy, law, mass-communication, pharmacy, tourism and hospitality and entertainment industries come easily to mind. ${ }^{50}$

Through her membership of independent school Proprietors Association, Mrs. Esan contributed to the growth of private schools and development of remedial education. Mrs. Wuraola Esan was aware of the need for private school owners to come together to discuss common problems. She believed further that an association of private school proprietors was necessary to serve as a pressure group. On her inspiration and that of Chief T.L. Oyesina, founder of Ibadan Boys High School, the Independent School Proprietors Association was floated. ${ }^{51}$ With her influence as a woman leader in the Action Group, the ruling party in the Western region and the only woman senator of the Federal Republic of Nigeria, Wuraola was able to get approval for official recognition of the body by the Western Region Ministry of Education. The Association came to the aid of private schools struggling to find their feet. Mrs. Esan was aware of the fact that private school owners faced enormous challenges. Perhaps, one of the most important services she rendered in collaboration with Chief Oyesina on behalf of the Association was the negotiation she had with the Chief Inspector of Education, Western Provinces that the Association be officially recognized as an Examining Body, for the Standard Six Certificate Examinations. This was at a time when the Ministry of Education was undertaking in the decentralization of the important First School Leaving Certificate Examination. Recognised schools were given the freedom of setting questions, marking them and recommending successful students for the award of Standard Six Certificate. Such recognition conferred a special privilege on schools that were recognized. Pupils flocked into such lucky schools. Parents knew that children who attended such schools would not encounter much problem of obtaining certificates at the end of their school programme.

Government schools had no major problem of getting government recognition. Mission schools had some difficulty in getting suitable staff and provision of facilities including school halls and essential equipment. 
Private schools, too, desired such enviable status as possessed by the recognized schools. ${ }^{52}$ This was where Mrs. Esan's successful intervention was most helpful and rewarding.

Mrs. Esan's courage, commitment, struggles and achievements contributed in no mean measure to the growth and expansion of private school establishments in Nigeria. ${ }^{53}$ She successfully demonstrated that there was merit in the establishment of private schools. Many Nigerians who shared her joy, excitement, enthusiasm, and who were equally interested in helping those boys and girls who could not get admission into the so-called recognized schools decided to run similar schools. Many of them were encouraged and inspired by the efforts of people like Mrs. Esan. A story of her failure could have created doubts in the minds of those sitting on the fence as regards the wisdom of establishing private schools on their own. Interested educationists started inundating the Department of Education with requests for the opening of private schools with the objective, "to diffuse scholarship among those who for some reasons can no longer attend a day school". ${ }^{54}$ University Evening classes were established in Lagos; from Ijebu-Igbo came an application from one Mr. (later Professor) S.O. Awokoya to the Chief Inspector of Education requesting if he could be permitted to establish a school for those "junior teachers and workers in Ijebu-Igbo, people whose education has been cut short earlier than they desired". ${ }^{55}$ In 1949, Canon I.G.A. Jadesimi also requested for permission to open an Evening Class in IjebuOde. In 1963, Mr. J.S. Ogunlesi and his wife opened Olowu Educational Services which gave birth to Ibadan Children Home School which Mrs. Ogunlesi managed for many years in Ibadan while Rev. Canon, (later Archdeacon) Emmanuel Oladipupo Alayande of the Ibadan Grammar School fame established the Ibadan Evening Tutorial Classes to provide remedial education for those who would have otherwise been denied the benefit of further education. ${ }^{56}$ Thus, Mrs. Wuraola Esan wittingly and unwittingly helped to provide remedial education for those less priviledged Nigerians who could not gain admission into the regular school system to fulfil their life ambition of acquiring further education.

Mrs. Esan also encouraged and promoted the institution of day students. We have already seen from the above that Wuraola was often reluctant to send students out of her school for inability to pay school fees. Although, she admitted students who could not afford the school fees, majority of her students came from homes in the lower middle socio-economic groupings. This meant that many could not afford to pay the necessary school fees. It was to help such parents with low incomes that Mrs. Wuraola Esan encouraged the institution of Day students. Such students could be fed at home and help their parents after school hours. Thus, boarding facilities were limited as many of the students population came to school from their homes.

Furthermore, Mrs. Wuraola Esan championed the cause for the provision of literacy opportunities for adult women who had missed formal education when they were young. She ran adult education classes for hundreds of market women in places like Ayeye, Aremo, Ogunpa, Dugbe. Thus, she helped in turning their lives around as many could now read, write and count in hundreds. ${ }^{57}$ It is important to note that many of such women later became her political foot-soldiers when she found herself actively engaged in the partisan politics of the First Republic. This may also have helped her in the effective and successful mobilization of women whilst she reigned as the new Iyalode (women leader) of Ibadan.

She also contributed her own quota to Nigerian educational reforms. One of the defects of the Nigerian educational system is that it places more emphasis on theory at the expense of the acquisition of practical knowledge. This often leads to rural-urban migrations, unemployment and the attendant social vices. Mrs. Wuraola was quick to identify these defects and attendant socio-economic challenges facing the youths. According to her:

Our manpower wastage is very high because of the wrong education given to our children. After their graduation, they rush to our urban centres to look for white collar jobs that are not easy to get: our system of education is totally faulty. That is why we have so many people rushing to cities like Ibadan, Enugu and Lagos, the federal capital territory to find work. ${ }^{87}$

Her anti-dote to this problem could be found in the curriculum she designed for her school which emphasized vocational/technical skills. Her liberal curriculum gave her products the opportunity to have alternative choices. Those who appeared to have the necessary abilities for rigorous academic pursuit had the priviledge of acquiring technical/vocational education which lays emphasis on life-skills. Thus, before the 6-3-3-4 programme of education was introduced into the Nigerian School Curriculum in the late 1980s, Mrs. Esan was already practising it in her own school, although on a modest scale. 
Mrs. Esan's contribution to science education is no less important. She and her daughter, Yetunde Omisade not only made a great impact on the teaching of science in the Peoples Girls Grammar School, but also encouraged many girls to study science subjects. Mrs. Esan reportedly believed that science education was basic to success in any human endeavour and that science was the pivot around which the greatness of any nation depended. ${ }^{59}$ She was, perhaps, not unaware of the advancement made in the sciences and technology by great nations like Russia, Japan, Germany and the USA. She believed that for Ibadan and in fact, Nigeria as a whole to be great, Science subjects must be encouraged right from secondary school level. This explains why she introduced the teaching of the sciences in her school in the 1970s.

Mrs. Esan's commitment to and encouragement of Science has produced many Science graduates for Ibadan in particular and the Nigerian nation in general. A few of these include Dr. Sola Idowu, a medical doctor, Adeola Akisemolu, A Microbiologist and Mrs. Afuwape a botanist, among several others. ${ }^{60}$

As discussed above, Wuraola contributed in her own little way to educational administration, planning and management. It is true that her exposure to formal education was little compared to the standard of today. But she would surprise many of today's holders of Bachelor degree certificates in Educational administration by her knowledge and depth in learning. In recognition of the need to have a regular pool into her secondary school section, she established Nursery and Primary schools where Arithmetic, English and Civic education were taught. At the end of the elementary education, the best students were selected for admission into the secondary school. The above was the background to the establishment of Dorcas Memorial Nursery and Primary school which served as feeders for the secondary modern school and later Peoples Girls Grammar School.

\section{Conclusion}

It is clear beyond doubt from the foregoing that Mrs. Wuraola was an uncommon school proprietor, teacher and, manager, whose activities brought positive changes to Ibadan and Peoples Girls Institutions in Ibadan. Her initiatives and sacrifices were aimed at promoting the education of girls, thus liberating the womenfolk from ignorance and societal discrimination and, transform the perception of the Ibadan to education of girls at the grassroots. However, she was not a lone ranger in the difficult task of realizing her ambition she acquired the services of other patriotic men and women who complemented her efforts for the task of uplifting the status of women in Ibadan. She impacted positively on the growth and development of vocational, technical and commercial education in Nigeria. She was a visionary woman with ideas and ideals which others helped her to translate to reality. She enjoyed the cooperation, loyalty and support of her equally reliable female teachers and the sympathetic support of government officials of the time. But this was not achieved without a cost to her marriage. However, she accomplished her mission.

\section{Notes and References}

[1]. Of these children, Wuraola's mother had four, three females and one male. Among her half-brothers and sisters were Pa Joseph Adeyemi Ojo, a Veteran teacher and footballer of King's College, Lagos, Chief E.A. Ade-Ojo, Lawyer and former Director of Texaco Oil (Nigeria) Limited, Architect A.O. Ojo of Allied Architects, Madam Grace Adekambi Agbe and Adeola Akinbiyi.

[2]. Yetunde Omisade and Jadesola Akande, A Brief History of Chief (Mrs.) Wuraola Esan" in Mojirayo Bello, (ed.) A Souvenir Magazine of the 21 Year Anniversary of the Peoples Girls Grammar School, Ibadan pp. 16-18.

[3]. Ahmadu Sesay and Adetanwa Odebiyi (eds.), Nigerian Women in Society and Development, Ibadan: Dokun Publishing House, 1998 , p. 17

[4]. Ladipo Abimbola Sinat, "The Life and Times of Chief (Mrs.) Wuraola Adepeju Esan, The Iyalode of Ibadan", Project Essay, Department of History and International Studies, Lagos State Unviersity, Ojo, Lagos, p. 5

[5]. "A Brief History of Chief (Mrs.) Wuraola Esan" in her Funeral Ceremony Pamphlet, (1985), p. 20

[6]. National Archives Ibadan (N.A.I.) Ibadan Ministry of Education (IBMINED) 1/6 Volume 1: Akure Training Centre, 1927-1937.

[7]. Mrs. Yetunde Omisade, "Biography of Chief (Mrs.) Wuraola Esan" (an unpublished manuscript (no date).

[8]. J.F. Sokoya, "The Ideal Senior Tutor: Venerable Archdeacon S.A. Banjo" The SACOBA: The Half-Yearly Newsletter of St. Andrews College Old Boys Association, July, 1986, p. 25.

[9]. Oral interview with Chief (Mrs.) Alice O. Longe, the Iya Ijo of CMS Church Aiyede, Ekiti, Aged 80+, retired school teacher and one of those closely acquainted with Mrs. Esan, at her residence, "Ibiyemi Pilgrims Solace", No. 7, Ibikunle Avenue, Bodija, Ibadan, 3/2/95.

[10]. See Babs A. Fafunwa, History of Education in Nigeria, Ibadan: NPS Educational Publishers Ltd., 1974, reprinted 2004, p. 104.

[11]. Oral Interview with Mrs. Alice O. Longe...

[12]. See M.A. Adeyemi, "Peoples Girls Grammar School", Mojirayo Bello (ed.) A Souvenir of Magazine of the 21 Year Anniversary of the Peoples Girls Grammar School, Ibadan, 1986.

[13]. T.V. Aderinola and E.A. Alayande, "Education in Ibadan", in IBADAN, Zaria: Gaskiya Corporation, December 1949.

[14]. G.O. Ogunremi (ed.), IBADAN: An Historical, Cultural and Socio-Economic Development of an African City, Ibadan, Modelor Press, 1999, p. 415

[15]. See NAI, Annual Report 1937

[16]. Toyin Falola, Politics and Economy in Ibadan, 1893 - 1945, Ibadan: Modelor Publishers, 1989, p. 263

[17]. NAI, CSO (26) Oyoprof, Annual Report., 1941, p. 9

[18]. NAI, CSO (26) Oyoprof, Annual Report., 1941, p. 9

[19]. NAI, CSO (26) Oyoprof, Annual Report., 1941, p. 9 
[20]. E.O. Adeoti, Alayande As Educationist, 1948-1983: A Study of Alayande's Contribution to Education and Social Change in Ibadan, Ibadan Heinemann Educational Books Plc, 1997, p. 24

[21]. Ahmadu Sesay and Adetonwa Odebiyi (eds.), Women in Society and Development, Ibadan: Dokun Publishing House, 1998, p. 9294.

[22]. A. Sesay and A. Odebiyi, 1998, p. 94

[23]. NAI, Southern Nigeria Defender (Lagos), 8 January, 1945.

[24]. Journal of Arts and Social Sciences (JASSLINK) a Publication of Adeniran Ogunsanya College of Education, Otto-Ijanikin, Lagos Vol. 8, No. 1, August, 2006.

[25]. Paraphrased from Journal of Arts and Social Sciences JASSLINK Vol. 8, No. 1, August, 2006, A Publication of Adeniran Ogunsanya Collegeof Education, Otto-Ijanikin, Lagos, p. 49.

[26]. NAI, Southern Nigeria Defender

[27]. C.A. Taiwo, Nigerian Educational System, Past, Present and Future, Lagos: Thomas Nelson (Nig.) Ltd., 1981, p. 71.

[28]. C.A. Taiwo, Nigerian Educational System, Past, Present and Future, Lagos: Thomas Nelson (Nig.) Ltd., 1981, p. 71.

[29]. NAI IBMINED 1/10 File No. 0118/1343 Vernacular Schools, File No. 0.118/1305 Vernacular Schools.

[30]. NIA, File Nos. 0.118/1367, 0.118/1239 Vernacular Schools. These were the Junior Elementary Schools whose teachers held only Elementary School Leaving Certificates.

[31]. NAI, File Nos. 0.118/1367, 0.118/1239 Vernacular Schools. These were the Junior Elementary Schools whose teachers held only Elementary School Leaving Certificates.

[32]. Oral interview with Mrs. Kemi Morgan, Aged 80+, retired school teacher and local historian at her residence Adeyinka Morgan Street, off Ososami Road, Oke-Ado, Ibadan, 29 April, 1992.

[33]. Toyin Falola, Politics and Economy in Ibadan, 1898-1945, Ibadan: Modelor Publishers, 1989, p. 263.

[34]. NAI IBMINED 1/6 Vol. 1,Akure Women Training Centre 1927-1937.

[35]. See T.V. Aderinola AndE.A. Alayande, Education in Ibadan, in IBADAN, Zaria: Gaskiya Corporation, Dec., 1949, p. 45.

[36]. Oral Interview with Mrs. Kemi Morgan...Op.cit

[37]. Yetunde Omisade, "Biography of Chief (Mrs.) Wuraola Esan..." Op.cit

[38]. Ibadan Ministry of Information, Report of the (Banju) Commission Appointed to Review the Educational System of Western Region, Ibadan: Government Printer, 1961.

[39]. See J.O. Akande, Saturday's Child: Profile of Chief Wuraola Esan, Lagos: Wurakay Publishers, 1986.

[40]. J.O. Akande, Saturday's Child: Profile of Chief Wuraola Esan, Lagos: Wurakay Publishers, 1986.

[41]. J.O. Akande, Saturday's Child: Profile of Chief Wuraola Esan, Lagos: Wurakay Publishers, 1986.

[42]. J.O. Akande, Saturday's Child: Profile of Chief Wuraola Esan, Lagos: Wurakay Publishers, 1986.

[43]. A.S. Ladipo, , The Life and Times of Chief (Mrs.) Wuraola...

[44]. Yetunde Omisade, Jadesola Akande, et als, "A Brief History of Chief (Mrs.) Wuraola Adepeju Esan... p.2

[45]. A.S. Ladipo...

[46]. A.S. Ladipo . p. 27

[47]. A.S. Ladipo p. 28

[48]. A.S. Ladipo p. 29

[49]. Oral interview with Mrs. A. Obembe, 50+ St. Leoi's Primary School, Orita-Challenge, Ibadan and Mr. Emmanuel Fafore, 50+ Headmaster, Letmot Primary School, Mokola, Ibadan.

[50]. Oral interview with Mrs. A.O. Adekunle, Aged 50+ Principal, Peoples Girls Grammar School (Senior School) Molete, Ibadan, 14 Nov., 2011.

[51]. M. Omolewa, The Life and Times of Chief T.L. Oyesina: The Study of A Pioneer in African Education and Youth Leader, Ibadan: Abiprint \& Pak Ltd., Publishing Division, 1981, p. 55

[52]. M. Omolewa, 1981, p. 57

[53]. Oral Interview with Mrs.Obembe..

[54]. Oral Interview with Mrs.Obembe..

[55]. Oral Interview with Mrs.Obembe...

[56]. E.O. Adeoti, Alayande As Educationist..., 1997, pp. 159-160

[57]. Oral Interview with Mrs. Kemi Morgan...

[58]. A.S. Ladipo, The Life and Times of Chief Wuraola Adepeju Esan... Op.cit p.25

[59]. Oral Interview with Chief (-Mrs.) Alice Longe...

[60]. Yetunde Omisade, Jadesola Akande, "A Brief History of Chief (Mrs.) Wuraola..." p.2 